\title{
Pengaruh Islam Terhadap Budaya Kerja Suku Sasak
}

\author{
Oleh : H.Muhasim
}

\author{
Bismillahirrahmanirrahim. \\ Permohonan kepada selain Allah, adalah pelecehan terhadap martabat \\ manusia. \\ Dasar pemikiran " Hanya Engkaulah yang kami sembah, dan hanya kepada \\ Eanghkaulah kami memohon pertolongan". sekelumit kata-kata suci \\ mengawali artikel ini, semoga mendatangkan rakhmat, Amin.
}

\begin{abstract}
Lombok Island, the island in 1000 (one thousand) mosque, which is the place of domicile sasak, which is majority Muslim. Islam is meant here is based on the creed of monotheism, Shari' a and morals, with sincerity, priests and science. Islam is the doctrine of truth that comes from God the Creator, except that there is an act of culture and human behavior. Therefore, Islam and culture are two different sides, and may influence each other.
\end{abstract} Culture sasak unique and different than the culture of 1,300 -suku tribal cultures that exist in Indonesia. No wonder many kumunitas complaining sasak culture, there is an opinion similar to the culture of Balinese or Javanese tribe, but all including the culture of Indonesia. This report explores the influence of Islam teradap sasak work culture, using descriptive method, so it can be viewed in a straightforward and cultural influences sasak both from the application of Islamic values, cultural traits sasak and the influence of the teachings of Islam to the formation of the work culture. The influence can be negative, such as a misguided understanding of the teachings and values of Islam, the rise of terrorism, Kekeran among fellow citizens, and between religions, but in this article is meant to influence is the nature pesitif that is affecting a culture of co sasak based values of Islam. The problem is there are parties in the name of Islam, but the way, his behavior is wrong, such as terrorism, the Kekeran between Warg and inter-religious, it is not the true teachings of Islam and not the intended human culture. Faith in Islam can grow, can also be reduced, can be strong, very strong, can be weak, very weak, could even disappear alias be hypocritical. It could be any identity as followers of Islam, but the attitude, the nature, behavior and culture, away from the teachings of Islam, such as terrorism and acts of violence. This article could be a solution to the problem at hand, evoke memories of fellow citizens so it stays on the right track according to religious teachings. Provide motivation, innovation and foster creativity work, which has positive influence on the culture of the working people, especially susku sasak, which 
not only sasak that berdommisili in Lombok, but wherever domiciled, whether as a power Transimigrasi or who are into the workforce in the neighboring country

Keyword: The influence of Islam, work culture sasak.

Abstrak: Pulau Lombok, pulau 1000 ( seribu) Masjid, yang merupakan tempat domisili suku sasak, yang mayoritas memeluk agama Islam. Islam dimaksud disini adalah didasari Aqidah tauhid, Syari'at dan akhlak, disertai keikhlasan, imam dan ilmu. Islam adalah ajaran kebenaran yang datangnya dari Allah Sang Pencipta, selain itu ada kebudayaan yang merupakan perbuatan dan perilaku manusia. Oleh karena itu Islam dan kebudayaan merupakan dua sisi yang berbeda, dan bisa saja saling mempengaruhi.

Budaya suku sasak unik dan berbeda dibanding dengan budaya dari 1.300 budaya suku -suku yang ada di Indonesia. Tidak heran banyak kumunitas yang mengkomplain budaya suku sasak, ada yang berpendapat mirip dengan budaya Suku Bali atau suku Jawa, namun kesemuanya termasuk kebudayaan Bangsa Indonesia. Tulisan ini mencoba membahas pengaruh islam teradap budaya kerja suku sasak, menggunakan metode deskriptif, sehingga bisa melihat secara lugas pengaruh dan budaya suku sasak baik dari sisi aplikasi nilai- nilai islam, ciri-ciri budaya suku sasak dan pengaruh ajaran islam terhadap pembentukan budaya kerja.

Pengaruh bisa saja negatif, seperti terjadinya salah kaprah pemahaman ajaran dan nilai-islam, munculnya terorisme, kekeran antar sesama warga negara, dan antar agama, tetapi dalam artikel ini yang dimaksud dengan pengaruh adalah yang bersifat pesitif yaitu yang berpengaruh terhadap terbentuknya budaya kerja suku sasak yang berbasis nila-nilai Islam.

Masalahnya terdapat pihak-pihak mengatas namakan Islam, tetapi caranya, perilakunya salah, seperti terorisme,terjadinya kekeran antar warg dan antar agama, itu bukanlah ajaran Islam yang benar dan bukanlah merupakan kebudayaan manusia yang dimaksudkan. Keimanan dalam Islam bisa bertambah, bisa juga berkurang, bisa kuat, sangat kuat, bisa lemah, sangat lemah, bahkan bisa hilang alias menjadi munafik. Bisa jadi identitas saja sebagai penganut Islam, namun sikap, sifat, perilaku dan budayanya, jauh dari ajaran Islam, misalnya terorisme dan tindakan kekerasan. artikel ini bisa menjadi solusi masalah yang sedang dihadapi, membangkitkan ingatan sesama warga masyarakat 
sehingga tetap berada pada jalur yang benar sesuai ajaran agama. Memberikan motivasi, inovasi dan menumbuhkan kreatifitas kerja, yang berpengaruh positif terhadap terciptanya budaya kerja masyarakat, khususnya susku sasak, yang bukan saja suku sasak yang berdommisili di Lombok, tetapi dimana saja berdomisili, apakah sebagai tenaga Transimigrasi ataupun yang sedang menjadi tenaga kerja di negeri jiran.

\section{Kata Kunci : Pengaruh, Islam, Budaya Kerja, Suku sasak.}

\section{A. Pendahuluan.}

Suku sasak yang mendiami Pulau Lombok 4000 tahun sudah, dalam perilaku, tata kehidupan dan pergaulannya tercermin sebagai penganut Agama Islam. Masuknya Islam di Lombok berkembang beberapa pendapat. Pendapat yang pertama mengatakan bahwa Islam masuk di Lombok dari Makasar lewat Sumbawa kira-kira permulaan abad 16 yang dibawa oleh Sunan Perapen putra dari Sunan Giri. Pendapat terkuat menyebutkan bahwa islam masuk di Lombok untuk pertama kalinya sekitar abad ke-13 Masehi (antara tahun 1201 hingga 1300 Masehi). Dibawa oleh muballiq dari Bagdad( Irak ) bernama AsySyaikh As-Sayyid Nūrurrasyīd Ibnu Hajar al-Haytami. Masyarakat Pulau Lombok secara turun-temurun lebih mengenal dia dengan sebutan 'Ghaus 'Abdurrazzāq'. Dia selain sebagai penyebar

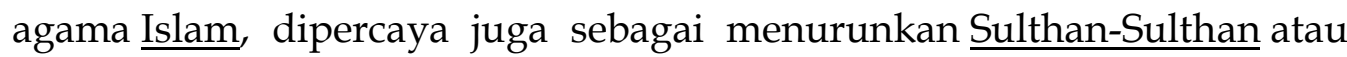
raja - raja dari kerajaan-kerajaan yang ada di Pulau Lombok. Artinya bahwa Sulthan-Sulthan atau raja- raja kerajaan di Lombok sebagai penganut agama Islam.

Lombok, selain terkenal karena sejarah dan hasil budayanya, kondisi alam Pulau Lombok Indah dan menawan, kekayaan alam yang berlimpah, masyarakatnya ramah dan sederhana, sehingga daerah- 
daerah lain tertarik dan ingin ikut menikmati. Lihat saja sekarang banyak perantauan yang mengembangkan mata pencarian dari berdagang baik mikro, kecik maupun besar, bahkan lebih sukses dari suku sasak sendiri, dan memilih berdomisili di Lombok.

Budaya suku sasak unik dan berbeda dibanding dengan budaya dari 1.300 budaya suku -suku yang ada di Indonesia. Tidak heran banyak kumunitas yang mengkomplain budaya suku sasak, ada yang berpendapat mirip dengan budaya Suku Bali atau suku Jawa, namun kesemuanya termasuk kebudayaan Bangsa Indonesia. Kebudayaan bangsa ialah kebudayaan yang timbul sebagai sebuah usaha budinya rakyat Indonesia seluruhnya. Budi berasal dari kata buddhi bentuk jamak dari budhayyah, berasal dari bahasa Sanskerta yang berarti budi atau akal. Dalam bahasa Inggris, kebudayaan disebut culture, yang berasal dari kata Latin Colere, yaitu mengolah atau mengerjakan. Kata culture juga kadang diterjemahkan sebagai "kultur" dalam bahasa Indonesia. Koentjaraningrat (1990), menyatakan bahwa kebudayaan adalah: "Keseluruhan sistem gagasan, tindakan, dan hasil karya manusia dalam rangka kehidupan masyarakat yang dijadikan milik diri manusia dengan belajar".

Berbicara budaya kerja, patut disimak pendapat Drs. Gering Supriyadi,MM dan Drs. Tri Guno, LLM yang mengatakan bahwa Budaya Kerja adalah suatu falsafah dengan didasari pandangan hidup sebagai nilai-nilai yang menjadi sifat, kebiasaan dan juga pendorong yang dibudayakan dalam suatu kelompok dan tercermin dalam sikap menjadi perilaku, cita-cita, pendapat, pandangan serta tindakan yang terwujud sebagai kerja. Sifat manusia yang berbudaya kerja dalam bentuk yang 
abstrak dan perilaku yang bisa mengahsilkan karya. Demikian pula halnya dengan cita-cita, adat istiadat, masih bersifat abstrak, bisa berwujud karya, perilaku dan tata kehidupan. Banyak orang memiliki pendapat, memiliki ide atau saran bagi orang atau kelompok lain, tetapi yang baik dan bermakna, jika terwujud dalam karya yang mengahasilkan serta dapat merubah nasib masyarakat menjadi lebih baik. Allah Yang Maha Kuasa pun menegaskan dalam Firman " Sesungguhnya Allah tidak akan merubah apa yang ada disuatu kaum sehingga mereka merubah sendiri apa yang ada pada diri mereka ( Q.S. Ar Ra'du;11)

Inti dari definisi dan Firma Allah SWT, dapat disimpulkan bahwa manusia diciptakan Allah dengan akal, budhi, dapat terwujud budaya dan dengan budaya serta akalnya, manusia merubah nasibnya yang buruk menjadi baik, yang miskin menjadi sejahtera. Budaya menurut penulis merupakan hal yang kompleks, tidak bisa berjalan sendiri-sendiri, merupakan sebuah sistem yang saling ketergantungan antara pendidikan, pengetahuan, skill, falsafah sifat manusia dan agamanya. Pengetahuan, skill tercipta karena pendidikan, selanjutnya pendidikan yang berkarakter, akan melahirkan sifat manusia yang bermoral, beradat dan akan tercermin dalam perilaku positif. Perilaku manusia yang positif, melahirkan budaya kerja yang produktif, kreatif, inovatif, memiliki pandangan hidup yang luas, mampu menerima pendapat orang lain, pada akhirnya membentuk budaya kerja dengan berbasis nilai-nilai Islam.

Pendidikan menjadi jembatan untuk pengetahuan, skill, dan menciptakan manusia yang berkarakter Islami, sehingga dia dapat menggunakan akalnya dengan jujur dan bertanggung jawab. Secara 
logika manusia yang diciptakan sebagai mahluk yang memiliki akal atau budi, dan dengan potensi yang dimiliki menciptakan gagasan. Manusia menciptakan karya dengan tangannya sendiri, itulah kemudian manusia disebut sebagai khalifah atau pemimpin dibumi. Manusia selain memimpin dirinya, juga harus berhadapan dengan orang lain dan lingkungan global yang terus berubah. Perubahan, merupakan fenomena sosial yang kekal, siapapun dan kapanpun pasti berhadapan dengan perubahan, tidak ada istilah tidak menerima, karena perubahan itu akan datang dengan sendirinya, tanpa diminta.

Permasalahan yang dihadapi, kita merujuk pendapat Muchtar Lubis ( 2008;16 ). Mendaftar kelemahan mentalitas orang Indonesia seperti sifat munafik ( hifokrit), tidak bertanggung jawab, berjiwa feodal, percaya pada tahayyul, artistik yang cendrung erotis, lemah karakter dan berorientasi ke masa lampau. Akmulusi dari permasalahan tersebut diatas, dengan kondisi suku sasak saat ini, memiliki pendidikan rendah, kemampuan dan skil, tidak sebanding dengan permintaan pasar global. Sehingga budaya kerja masyarakat lokal terancam tergilas.

Berdasarkan pemaparan tersebut diatas, dan untuk mengantisipasi pengaruh budaya global serta membangkitkan budaya kerja, penulis merasa hal ini sangat penting dikaji. Oleh karena itu, dalam mengkajinya penulis mengambil judul " Pengaruh Islam, terhadap Pembentukan Budaya Kerja Suku Sasak “. Tulisan ini akan fokus pada masalah-masalah sbb;

1. Menggali nilai-nilai Islam yang berkembang Pada Suku sasak.

2. Mencari ciri-ciri budaya kerja suku sasak.

3. Pengaruh Islam Terhadap Budaya kerja suku sasak. 
Tulisan ini menggunakan pendekatan deskriptif, artinya menggambarkan suatu permasalahan yang terjadi dimasyarakat, menggunakan dokumen sejarah, sumber yang dapat dipercaya, tulisan pada media online, dan lainnya.

\section{B. Nilai-nilai Islam yang Berkembang Pada Suku sasak.}

Suku sasak termasuk penganut yang panatik terhadap ajaran Islam. Bacaan

“Bismillahirahmanirrahim”, menjadi pembukaan seluruh aktifitas suku sasak, bahkan memiliki caranya sendiri dalam mengaflikasikan keyakinannya itu, baik dalam pelaksanaan adat istiadat, budaya termasuk dalam prosesi perkawinan, tetap mendasarkan dirinya pada ajaran Islam. Kepercayaan kepada nilai-nilai Islam itu, tetap mewarnai kehidupan sehari-hari, selain yang memang bersifat Syari'at sebagi kewajiban rutin seperti melaksankan shalat lima waktu dan kegiatan ibadah muamalah lainnya. Anak-anak sudah mulai dibudayakan pengamalan nilai-nilai ajaran islam, do'a makan, do'a tidur, do'a masuk dan keluar kamar mandi dan lainnya. Nilai- ajaran agama Islam sangat dujunjung tinggi sebagai Firman Allah " Hai manusia sesungguhnya telah datang kepadamu dari Tuhanmu nasehat agama) dan penawar apa yang ada dalam dada atau rohani ( Q.S. Yunus;57).

Jadi menurut hasil penelitian sarjana dan ulama serta ketetapan Allah, bahwa ciri khas manusia itu ialah agama. Manusia yang tidak beragama dinyatakan sebagai hewan. Para sarjana telah dapat membuktikan, bahwa satu-satunya agama yang benar adalah Islam, seperi pembuktian yang dilakukan oleh Dr.Maurice Bucaille dan 
Dr.Syauki Futaki (Zalminal Zaini. 52). Demikian dalam Firman Allah " sesungguhnya agama disisi Allah adalah Islam ( Q.S. Ali Imran;19 ), bahkan anak sejak dilahirkanpun sudah diatur oleh-Nya , dalam Firman- Nya“ Tidaklah dilahirkan seorang anak melainkan atas agama ini ( Islam ) ( HR.Muslim).

Dr. Paryana Suryadiputra, mengemukakan dengan tegas perbedaan manusia dengan hewan, dalam bukunya" Manusia dengan atomnya dalam keadaan sehat dan sakit", lanjut mengatakan" Lain daripada itu pada manusia terdapat instink yang tidak terdapat pada hewan dan oleh karena itu merupakan satu-satunya sifat manusia, yang dapat membedakan manusia dengan hewan, yakni insting keagamaan ( religius instink ).

Agama telah menjadi bagian tidak terpisah dari kehidupan manusia. Seiring dengan dinamika perkembangan zaman, agama menghadapi berbagai tantangan yang tidak ringan. Salah satu bentuk tantangannya adalah kecenderungan sebagian orang atau kelompok untuk menjadikan agama justru terjatuh pada posisi yang rendah. Agama yang seharusnya menjadi petunjuk hidup dan sarat dengan nilainilai kebajikan, justru digunakan untuk berbagai kepentingan praktis yang bertentangan dengan ajaran agama itu sendiri. Hal ini ditandai juga dengan-salah satunya-munculnya konflik dan kekerasan dari para penganut, contohnya Terorisme.

Dari sudut pandang agama dapat dikatakan bahwa kunci dunia dan segala kodratnya terletak dalam diri kita sendiri dan setiap upaya yang sesuai dengan fitrah kita secara utuh. (Frithjof Schuon, The Transfiguration of Man: 42- 44). Ini bermakna bahwa kunci untuk 
menyelesaikan setiap persoalan ada dalam diri kita. Dalam ikhtiar penyelesaian ini, dibutuhkan penafsiran terhadap ajaran agama. Namun dalam kerangka Schuon, semua ikhtiar penyelesaian yang dilakukan seyogyanya selaras dengan fitrah manusia. Perspektif Schuon, dalam memandang persoalan yang dihadapi oleh agama ini menarik karena justru mengembalikan segala persoalannya kepada manusia sendiri. Pada diri manusialah terletak solusi tersebut. Artinya, manusia yang harus berikhtiar semaksimal mungkin untuk menghadapi. Hal itu tepat dengan Firman Allah "Sesungguhnya Allah tidak akan merubah apa yang ada disuatu kaum sehingga mereka merubah sendiri apa yang ada pada diri mereka ( Q.S. Ar Ra'du;11)

Hidup penuh harapan, dan bermakna jika dia terus berjuang dengan landasan Iman dan taqwa, Firman Allah" Tidak ada orang yang berputus asa dari rakhmat Tuhan-Nya kecuali orang yang sesat " ( AlHijr:50 ). Adapun orang yang berputus asa termasuk dalam golongan kufur,sebagaimana firman-Nya " sesungguhnya, tiada berputus asa dari rahmat Allah, melainkan kaum yang kafir ".( Yusuf:87, al-Hijr :55 ). Dalam aplikasi ajaran Islam tentu akan bersentuhan dengan kebudayaan, yang merupakan produk manusia. Menurut Edward Burnett Tylor, kebudayaan merupakan keseluruhan yang kompleks, yang di dalamnya terkandung pengetahuan, kepercayaan, kesenian, moral, hukum, adat istiadat, dan kemampuan-kemampuan lain yang didapat seseorang sebagai anggota masyarakat. Kita pilah mana produk manusia dan mana produk yang berdasarkan nilai yang didasai keyakinan. Pengetahuan, kemampuan, kesenian, adat istiadat merupakan produk pendidikan artinya produk manusia. Moral dan hukum bisa terbentuk berdasarkan 
kepercayaan atau keyakinan manusia, hukum bisa berdasarkan Alqur'an, bisa juga merupakan hukum nasional.

Kehidupan suku sasak didasari ajaran Islam, selain Ideologi Kebangsaan yaitu Pancasasila dan UUND 1945. Tata pergaulan, proses dalam berkehidupan, tidak terlepas dari nilai - nilai keyakinannya, dan Idelogi kebangsaannya. NILAI ajaran Islam, sebagai konsep penghargaan tinggi yg diberikan oleh warga masyarakat kepada beberapa masalah pokok kehidupan keagamaan yang bersifat suci sehingga menjadi pedoman bagi tingkah laku keagamaan warga masyarakat setempat. Nilai-nilai ajaran Islam, membentuk jati diri yang menimbulkan suatu kekuatan, membentuk budaya kerja, sebagaimana tergambar dalam budaya suku sasak, seperti suka kerja secara gotong royong, beramal dalam kegiatan pembangunan Masjid. Pembangunan Sekolah keagamaan/Madrasah, pembangunan tempat-tempat peribatan, menggarap tanah sawah, karena sebagian besar suku sasak bermata pencaharian dari pertanian. Demikian pula dalam upacara keagaaman, Maulid nabi, Isyro' dan Mi'raj, hari raya qurban dan upacara perkawinan, dilaksanakan secara gotong royong, kerjasama dan sukarela.

Permasalahan yang muncul sebagai pengaruh negatif budaya global, lihat saja perilaku sebagian genersi muda kita, mulai meninggalkan adat istiadat, kearifan lokal, sudah bergaya masa kini, seperti cara-cara berpakaian, model terbuka atau tranparan, model rambut, tidak bisa dibedakan laki-laki dan perempuan, takut dikatakan tidak modern. Membuat tato yang biasanya menjadi simbul keperkasaan seorang preman, sekarang sudah dijadikan model, baik laki-laki maupun perempuan. Moral atau akhlak, tercemarkan, rasa malu sudah 
terkaburkan dengan gaya masa kini. Rasulullah SAW mengingatkan dalam bersabdanya "Malu adalah sebagian dari Iman, dan Iman itu adanya di Surga. Sikap tidak tahu malu adalah sebagaian dari pembangkangan kepada Allah dan sikap membangkang itu adanya di neraka (HR. Ahmad).

Bentuk malu itu berlainan dan bermacam-macam, ia tidak berupa satu macam ekspresi saja. Bahkan malu itu bisa berujud segala ucapan, gerakan, perbuatan, model, tata laku, yang muncul dari seseorang. Kita harus optimis mengahadapi arus yang mengancam punahnya budaya kerja lokal, nilai-nilai sebagai pondasi, bagaimana mengambalikan kerifan lokal, adat istiadat, " adat bersendi syara', syara' bersendi kitabullah". Hanya dengan demikian, upaya kita bisa membentuk budaya kerja Islam, yang dapat mengantarkan masyarakat kepada kehidupan yang lebih adil dan sejehtetra.

Permasalahan lainnya pengaruh kemajun tehnologi komunikasi, HP, TV, dan perkembangan alat komunikasi lainnya, seolaholah menjadi " juru sihir". bagi anak-anak usia sekolah, sehingga sulit meluangkan waktu untuk belajar, mengaji. Dulu kebiasaan suku sasak setiap usai shalat magrib, anak-anak mengaji di Langgar atau di Lumbung-lumbung atas bimbingan para ustaz, sekarang hampir tergilas. Banyak lagi contoh lain yang dulu tabu dilakukan didepan umum, pesta minuman keras, sekarang pamer ditempat terbuka. Pendidikan berkarakter berbasis agama islam, harus diperkuat, untuk menciptakan moral dan akhlak yang mulia.

\section{Ciri-ciri budaya kerja suku sasak..}


Budaya secara etimologis yaitu akal atau budi sedangkan kebudayaan adalah hasil kegiatan dan penciptaan batin dari akal manusia. Sikap ini bukan saja dimiliki oleh pribadi, tetapi juga oleh kelompok bahkan masyarakat. Budaya kerja dibentuk oleh berbagai kebiasaan, pengaruh budaya, serta sistem nilai yang diyakininya. Budaya juga mempunyai makna nilai moral adalah suatu pandangan batin yang bersifat mendarah daging, Dia merasakan bahwa hanya dengan menghasilkan pekerjaan yang terbaik, bahkan sempurna, nilai-nilai budaya yang dimiliki dapat terwujud. Https:// www: badriah27.wordspot.com “ Menujuk pendapat Suhandi (1994), menyebut kebudayaan memiliki ciri-ciri umum yaitu: Kebudayaan dipelajari, Kebudayaan diwariskan atau diteruskan, Kebudayaan hidup dalam masyarakat, Kebudayaan dikembangkan dan berubah, Kebudayaan itu terintegrasi.

Sebagaimana diuraikan di atas, budaya ada karena proses pendidikan dan ilmu, selain memang diwariskan dari leluhur, berkembang di masyarakat mengikuti perubahan zaman dan dapat saja budaya berintegrasi dengan budaya pendatang. Cermati saja bagaimana budaya suku sasak, dikomplain berasal dari budaya jawa dan Bali, dengan beberapa alasan yang memperkuat pendapat masing-masing. Berkembangnya ajaran Islam, terdapat perbedaan pendapat, selain adanya pengaruh intervensi kerajaan luar Lombok, Kerajaan Selaparang pernah ditaklukkan Kerajaan Majapahit, begitu juga Kerajaan Selaparang pernah dikuasai oleh kerajaan dari Bali.. Dengan tidak mempermasalahan kedua pendapat tersebut, simpulan yang bisa kita tarik untuk memperkuat tekat kita, antara lain, budaya suku sasak 
adalah budaya suku sasak yang diwariskan oleh leluhur, sehingga berkembang sampai sekarang.

Perkembangan ilmu dan keyakinan terhadap agama Islam merupakan ciri tersendiri, memperkaya hasanah budaya, sehingga suku sasak semakin arif dan bijak, memiliki budaya kerja Islami, serta memiliki jati diri sebgai manusia yang berkepribadian yang jujur, Ikhlas serta bertaqwa kepada Tuhan yang Maha Esa. Demikian juga menurut pendapat Suhandi, memperkuat pendapat Edward Burnett Tylor dan Drs. Gering Supriyadi,MM dan Drs. Tri Guno, LLM , Budaya Kerja adalah suatu falsafah dengan didasari pandangan hidup sebagai nilai-nilai yang menjadi sifat, kebiasaan dan juga pendorong yang dibudayakan dalam suatu kelompok dan tercermin dalam sikap menjadi perilaku, cita-cita, pendapat, pandangan serta tindakan yang terwujud sebagai karya.

Makna yang dapat disimpulkan dari pendapat para ahli tersebut, bahwa manusia dan budaya, ibarat sekeping mata uang, yang kedua sisinya berbeda, tetapi tidak dapat dipisahkan anara keduanya. Manusia diciptakan untuk menciptakan budaya, karena hanya manusia yang memiliki legalitas untuk itu. Hewan bagaimanpun jinaknya tidak dapat menggantikan posisi manusia. Berbudaya itulah menjadi ciri-ciri utama manusia, dan dengan budaya manusia tercipta budaya kerja. Sebagaimana diterangkan asal kata budaya yang bermakna akal atau budi. Secara umum budaya mengandung pengertian yaitu cara hidup, tatanan atau aturan perilaku dan tentang jalan hidup .

Dari pemaparan diatas penulis dapat menyimpulkan bahwa budaya kerja berarti cara atau aturan perilaku hidup. Jadi budaya kerja adalah refleksi dari nilai-nilai kehidupan yang tumbuh dan 
berkembang di masyarakat. Kembali kepada ciri budaya suku sasak, lihat bentuk fisik, bagaimana Lombok terkenal sebagai daerah 1000 ( SERIBU) MASJID. Tempat-tempat peribadatan tardisional, peningkalan leluhurnya menurut perkembngan sejarah kerajaan-kerajaan yang pernah ada di Lombok. Peningkatan sejarah itu memberikan ciri has tersendiri, Masjid Tua yang masih ada di Bayan, Kabupaten Lombok Utara, Masjid Tua, di Desa Songak Kecatan Sakra, terdapat diplaponnya atau langit-langitnya tertulis huruf alqur'an dalam bentuk kaligrafi. Belum lagi berupa seni tardisional berupa rumah adat yang ada di bayan, rumah adat yang di Sade, rumah adat yang ada di Sembalun Kabupaten Lombok Timur, dan banyak lagi berupa makam-makam para Wali yang menyebarkan Islam di Lombok. Wafatnya para wali, dimakamkan di Lombok seperti di makam Loang Balok Lombok Barat, Makam Nyatok di Lombok Tengah, yang konon dua makam ini merupakan maka orang yang sama. Makam Selaparang yang ada di Lombok Timur, yang satu ini sudah diangkat menjadi nama Bandara yang ada di Lombok yaitu bandara Selaparang.

Kesenian Suku sasak memang sangat berbeda ciri hasnya dengan budaya yang ada didaerah lain Indonesia, seperti perisaean, gasingan, jurakan. Perisaen merupakan kesenian adu kejantanan, khusus ini dilakukan oleh orang laki-laki. Konon menurut cerita suku sasak perisaean ini, dulu untuk melatih para pemuda sasak untuk berperang, atau bisa mempertahankan diri dari gangguan-gangguan penjajahan. Seninya mereka dalam bertanding, tidak ada unsur marah, mereka senyum sambil memukul. Setelah beradu, saling pukul, tidak ada dendam, alias setelah pertarungan usai, mereka saling merangkul, saling memaafkan. Gasingan orang sasak ini berbeda baik bentuk maupun 
aturan permainannya, kalaupun ada didaerah lain. Gasing besar, mereka namai pemantok, digunakan untuk menghantam gasing pengorong atau pelepas yang ukurannya lebih kecil. Begasingan berasal dari kata gang yang artinya "lokasi", dan dari kata sing artinya "suara". Permainan tradisional ini tak mengenal umur dan tempat, bisa siapa saja, bisa di mana saja. Sekarang ini pakaian para pemain gasingan, sudah dimodifikasi dengan berpakaian adat sasak.

Ciri-ciri khas kesenian suku sasak, antara lain Rudat, jangger, gendang beleq, belakangan ini berkembang sebuah seni rekayasa yang disebut kecimol. Rudat, jangger sering dipertunjukkan ketika ada hajatan dalam resepsi pesta perkawinan, hitanan, atau dalam pesta adat lainnya seperti pesta adat Bawu Nyale. Peringatan hari-besar nasional, seperti 17 Agustus, dan hari besar nasional lainnya. Sedang pada hari-hari besar Islam, suku sasak menggunakan kesenian yang bernafaskan Islami yaitu Qasidah Rebana, Tahfizulqur'an, seni baca Alqu'an, pengajian umum ( dakwah ).

Desain bangunan tradisional, Masjid kono peninggalan leluhur orang sasak itu, bentuk bangunan tinggi dan menggunakan tanah, walaupun tetap bernafaskan islami yaitu memiliki mimbar, dan menunjukkan bahwa itu tempat suci, juga ada batas alas kaki harus dilepas. Lumbung, suku sasak, desainnya bertiang empat ( disebut sekepat ), menyimbulkan Empat sahabatan Nabi besar Muhammad Saw. Ada yang desian bertiang Enam ( disebut) sekenem, ini menggarkan rukun Iman yang Enam. Kemudian baik disekepat dan skenem, dibuat tempat khusus di atas tempat duduk, yaitu tempat diletakkan kitab suci Alquran. Ciri-ciri budaya suku sasak baik dari seni pertunjukan, seni tari 
dan desain bangunan tradisonal untuk tidak menyebutnya Kuno, cocok dengan pendapat Koentjaraningrat yang mengatakan kebudayaan itu adalah keseluruhan gagasan dan karya manusia yang harus dibiasakan. Pembiasaan itulah akan memberikan pengaruh budaya kerja. Pengaruh, yaitu daya yang ada atau timbul dari sesuatu ( orang, benda) yang ikut membentuk watak, kepercayaan atau perbuatan seseorang. Pengaruh berupa kekuatan batin dan akal tercermin dalam pikiran manusia, terwujud dalam karya atau hasil, memberikan ciri-ciri khusus. Unsurunsur ciri-ciri khusus tersebut, masuk dalam pembentukan, dimana unsur-unsurnya diproses sehingga sampai mencapai perkembangan tertentu apakah dalam betuk barang atau jasa, yang dapat bernilai baik secara sosial atau ekonomis.

Memproses untuk mencapai kelas branding ( terkenal ), budaya sasak tidaklah semudah membalik tangan, perlu sentuhan-sentuhan tangan terampil, pola pikir maju, dengan pola berpikir sistem. Menuntut campur tangan berbagai pihak, baik pihak masyarakat, lembaga lembaga sosial dan pemerintah, sehingga ciri khas budaya yang semula hanya ide atau bentuk seni yang kurang bermakna, akan dapat menjadi sebuah ujud apakah dalam bentuk benda atau jasa mencapai kualitas brending. Kulaitas branding jelas akan menarik wisatawan untuk berwisata apakah wisata rohani, wisata nurani, atau wisata spiritual, insyaallah Lombok menjadi pulau kecil yang indah " the smoll is biutiful", terkenal diseluh dunia.

Apa makna yang dapat dipetik dari ciri-ciri khas budaya suku sasak terhadap pembentukan budaya kerja, ciri keyakinan terhadap agama Islam melahirkan sifat, sifat melahirkan sikap dan perilaku, 
artinya Agama Islam memang mempunyai pengaruh besar, sebagai dasar pembentukan budaya kerja tinggi. Namun dalam perkembangan kehidupan manusia dan budaya, bersamaan dengan berkembangnya budaya global, untuk tidak mengatakan tergilas, ya kita gunakan kearipan lokal suku sasak, untuk mengembangkan budaya kerja, suku sasak mengikuti perkembangan zaman. Walaupun dibandingkan dengan budaya kerja negara lain masih perlu memacu diri.

Sebagai pembanding, kita banding budaya kerja orang Indonesia dan orang jepang. Budaya kerja bangsa Indonesia, menurut Insititute for Management of Development, Swiss, World Competitiveness Book (2007), memberitakan bahwa pada tahun 2005, peringkat produktivitas kerja Indonesia berada pada posisi 59 dari 60 negara yang disurvei. Atau semakin turun ketimbang tahun 2001 yang mencapai urutan 46. Indonesia jauh dari Singapura (peringkat 1), Thailand (27), Malaysia (28), Korea (29), Cina (31), India (39), dan Filipina (49). Urutan peringkat ini berkaitan juga dengan kinerja pada dimensi lainnya yakni pada Economic Performance pada tahun 2005 berada pada urutan buncit yakni ke 60, Business Efficiency (59), dan Government Efficiency (55).

Permasalahan yang dihadapi Indonesia diduga karena rendahnya kualitas sumber daya manusia, Sumber daya manusia Indonesia, tidak mampu bersaing dengan tenega kerja dari negara ASEAN lainnya. Hal itu disebabkan antara lain faktor penguasaan bahasa dan skill. Pembanding lain yaitu budaya kerja orang Jepang, yang menggunakan budaya kerja Ukuran nilai dan disiplin kerja, yaitu jumlah waktu yang dihabiskannya di tempat kerja. Keadaan ini tentu sangat 
berbeda dengan budaya kerja orang Indonesia yang biasanya selalu ingin pulang lebih cepat. Di Jepang, orang yang pulang kerja lebih cepat selalu diberi berbagai stigma negatif, dianggap sebagai pekerja yang tidak penting, malas dan tidak produktif. Pembanding ini hanya sekedar untuk tahu saja, apakah orang Indonesia tidak bisa memperbaiki budaya kerjanya, tentu jawabannya bukan bisa atau tidak bisa, karena nilai-nilai ajaran Islam sudah memandu karah itu, tinggal bagaimana mengefektifkannya saja.

Bagaimana dengan budaya kerja suku sasak, mungkin tidak jauh beda dengan budaya kerja Orang Indonesia kebanayakan. Alangkah bijaknya jika pembanding budaya kerja Jepang, mungkin gengsi dituru, tetapi suku sasak dengan ciri-ciri khas budayanya yang unik, harus dapat memperbaikinya. Terbukanya pasar bebas, dihawatirkan tenaga kerja Indonesia, kalah bersaing dengan tenaga kerja dari negara ASEAN, yang lebih siap baik dari segi pengatahuan, bahasa dan skill yang dimiliki. Apakah suku sasak akan menjadi penonton setia atau suku sasak akan menjadi tamu, dirumah sendiri. Ironis memang, oleh karena itu bersiaplah untuk bersaing dan maju bersama, untuk kesejehteraan rakyat.

\section{E. Pengaruh Islam Terhadap Budaya kerja suku sasak.}

Pengaruh adalah daya yang ada atau timbul dari sesuatu ( orang atau benda) yang berkuasa atau berkuatan. Pengertian pengaruh menurut Suharsini Arikunto adalah suatu hubungan antara keadaan pertama dengan keadaan yang kedua terdapat hubungan sebab akibat. Keadaan pertama diperkirakan menjadi penyebab yang kedua. Keadaan pertama berpengaruh terhadap keadaan kedua. Adapun yang dimaksud 
pengaruh dalam artikel ini adalah bentuk hubungan antara nilai-nilai Islam dengan budaya kerja suku sasak. Berbicara masalah pengaruh bisa berkonotasi positif bisa juga negatif, tetapi yang dibicarakan dalam artikel ini adalah nilai Islam yang berkonotasi positif.

Islam dimaksud disini adalah didasari Aqidah tauhit, Syari'at dan akhlak, disertai keikhlasan, imam dan ilmu. Islam adalah ajaran kebenaran, dan kebudayaan adalah perilaku manusia menuju kebenaran. Oleh karena itu Islam dan kebudayaan merupakan dua sisi yang berbeda. Perkembangan sekarang, seseorang atau sekelompok orang, bisa jadi mengatas namakan Islam, tetapi caranya, perilakunya salah, seperti terorisme, itu bukanlah ajaran Islam yang benar dan bukanlah merupakan kebudayaan manusia yang dimaksudkan.

Alqur'an merupakan pedoman masyarakat Islam, Alqur'an mengandung perintah-perintah merupakan petunjuk bagi siapa yang mau melihatnya. Allah telah menjelaskan didalamnya kewajiban hukum, membedakan antara yang haram dan yang halal. Allah telak menurunkan Al-Qur'an untuk meluruskan dengan petunjuk kearah perjalanan kehidupan manusia. Didalamnya termasuk kebudayaan manusia yang memberikan konotasi positif, sehingga menghasilkan budaya kerja yang bermanfaat bagi manusia itu sendiri. Budaya yang bukan menceritakan kisah-kisah gaib sebagai cerita, contoh-contoh kebudayaan manusia zaman dahulu seperti budaya menyembah berhala, menyembah selain Tuhan. Islam adalah sebaik-baik apa yang dimiliki manusia dari setiap sisi-sisinya; ruh; akal; masyarakat; amaliyah; pemikiran ; ekonomi, peradaban/kebudayaan; dan juga pengajarnnya mampu membahagiakan manusia. 
Suku Sasakadalah suku bangsa yang mendiami pulau Lombok dan menggunakan bahasa Sasak. Sebagian besar suku Sasak beragama Islam, asal nama sasak kemungkinan berasal dari kata sak-sak yang artinya sampan. Dalam Kitab Negara Kertagama kata Sasak disebut menjadi satu dengan Pulau Lombok. Yakni Lombok Sasak Mirah Adhi. Dalam tradisi lisan warga setempat kata sasak dipercaya berasal dari kata "sa'-saq" yang artinya yang satu. Kemudian Lombok berasal dari kata Lomboq yang artinya lurus. Maka jika digabung kata Sa' Saq Lomboq artinya sesuatu yang lurus. banyak juga yang menerjemahkannya sebagai jalan yang lurus. Lomboq Mirah Sasak Adi adalah salah satu kutipan dari kakawin Nagarakretagama ( Desa warnana ), sebuah kitab yang memuat tentang kekuasaan dan kepemerintahan kerajaan Majapahit, gubahan Mpu Prapanca. kata "lombok" dalam bahasa kawi berarti lurus atau jujur, "Mirah" berarti permata, "sasak" berarti kenyataan dan "adi" artinya yang baik atau yang utama. Maka Lombok Mirah Sasak Adi berarti kejujuran adalah permata kenyataan yang baik atau utama.

Budaya Kerja, kita merujuk pendapat Drs. Gering Supriyadi,MM dan Drs. Tri Guno, LLM, mengatakan bahwa budaya kerja adalah suatu falsafah dengan didasari pandangan hidup sebagai nilainilai yang menjadi sifat, kebiasaan dan juga pendorong yang dibudayakan dalam suatu kelompok dan tercermin dalam sikap menjadi perilaku, cita-cita, pendapat, pandangan serta tindakan yang terwujud sebagai karya. Budaya atau kebudayaan adalah keseluruhan pengetahuan yang dipunyai oleh manusia sebagai mahkluk sosial yang isinya adalah perangkat-perangkat model-model pengetahuan yang secara selektif. Dapat digunakan untuk memahami dan menginterprestasi 
lingkungan yang di hadapi, dan untuk mendorong dan menciptakan tindakan-tindakan yang diperlukan.

Sedangkan perwujudan kebudayaan adalah benda-benda yang diciptakan oleh manusia sebagai makhluk yang berbudaya, berupa perilaku dan benda-benda yang bersifat nyata, misalnya pola-pola perilaku, bahasa, peralatan hidup, organisasi sosial, religi, seni. Bentuk fisik seperti Masjid, Langgar, Lumbung danlainnya,kesemuanya ditujukan untuk membantu manusia dalam melangsungkan kehidupan bermasyarakat. Lazimnya budaya seseorang atau masyarakat, dipengaruhi oleh nilai yang tumbuh dan berkembang yang didasari agama, keyakinan yang dia yakini oleh masyarakat tersebut. Demikian pula halnya dengan suku sasak yang keyakinannya terhadap agama islam, baik berdasarkan pendidikan atau Ilmu ataupun Islam keturunan, maka tentu nilai-nilai Islam akan berpengaruh terhadap pemebentukan budaya kerjanya.

Budaya kerja, adalah pembiasaan berproses dalam siklus yang terus berulang-ulang, sampai membentuk budaya kerja. Budaya kerja dibentuk oleh berbagai kebiasaan, pengaruh internal maupun eksternal, serta sistem nilai yang diyakininya karena suku sasak mayoritas memiliki keyakinan sebagai penganut agama islam, tentu akan melahirkan budaya kerja berbasis Islam.

\section{F. Simpulan.}

Suku sasak, mayoritas menganut Agama islam, secara turun temurun ataupun berdasarkan pendidikan dan ilmu yang dipelajarinya, baik melalui sekolah formal atapun melalui pendidikan non formal. 
Untuk memperkuat akidah, syaria'at dan akhlak, suku sasak mempunyai kebiasaan, secara rutin setiap seminggu sekali mengadakan dakwah Islamiah, di tempat-tempat peribadatan. Selain yang kita kenal, Lombok adalah pusat pondok pesantren terbesar di Nusa Tenggara Barat.

Lombok yang penduduknya mayoritas suku sasak dan penganut agama Islam, tentu mempunyai kebudayaan, baik dilihat dari sisi bahasa, adat istiadat atau perilaku, yang pada akhirnya budaya kerja suku sasak dipengaruhi oleh keyakinan yaitu milai-nilai Islam. Segala aktifitas hidupnya pasti dimulai dengan bernafaskan nilai -nilai Islami, minimal mengawali aktifitasnya dengan mengucap " Bismillahirrahmanirrahim" dan mengakhirinya dengan "Alhamdulillah", sebagai do'a ucapan syukur kepada Yang Maha Kuasa. Dari uraian -

uraian diatas dapat disimpulkan, ada pengaruh nilai-nilai Islam terhadap pembentukan budaya kerja suku sasak.

Alhamdulillah artikel ini juga dapat terselesaikan, berkat izin dan kehendak Allah Yanga Maha Kuasa juga, dan mudah-mudahan bermanfaat bagi masyarakat, dalam rangka meningkatkan amal ibadah dan budaya kerja masing-masing, baik perorangan maupun kelompok. Amin Yarabbal Alamin.

\section{Daftar Pustaka}

Al Qathani Said Bin Ali, Da'wah Bijak, Penerbit. PT.Gema Insani Press, Jakarta, Tahun 1994. 
Arifin Gus, Mintalah Kepada-KU, Penerbit PT.Alex Media Kompotindo, Jakarta, Tahun 2010.

Koentjoroningrat, Mentalitet Kebudayaan. Penerbit PT. Gramedia, Jakarta, Tahun 1974.

Myron Weiner, Modernisasi: Dinamika Pertumbuhan, Penerbit Voice of Amerikan Forum Lectures.

Muhammad AS.Hikam, Islam dan Pemberdayaan Civil Society, Penerbit.

Erlangga, Jakarta, Tahun 2000.

Masyhuri Syahid,M.A, K.H. Cambuk Hati, Penerbit PT. Irsyad Baitu Salam, Bandung, Tahun 2004.

Syahminan Zaini. Drs. “ Iman, Islam dan Amal “.Penerbit Kalam Ilmu, Malang, Tahun 1984.

Toto Tasmara K.H., Membudayakan Etos Kerja Islami, Penerbit PT.Gema Insani, Jakarta Tahun 2001.

Https:// www: badriah27.wordspot.com, Budaya Kerja . 